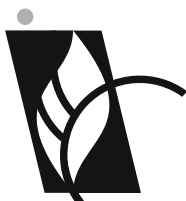

J O U R N A L

$\mathrm{O} F \bullet \mathrm{B} \mathrm{A} \mathrm{L} \mathrm{T} \mathrm{I} \mathrm{C}$

$S$ C I E N C E

E DUCATION

ISSN 1648-3898

Abstract. Students may acquire mislearnings in the course of their academic lives for various reasons and keep them for a lifetime. Some of the most common of those mislearnings are the alternative conceptions university students have about Biology lesson. This study was conducted through one-to-one interviews with 54 students at the 1st grade of the Department of Classroom Teaching in order to determine university students' alternative learnings about the classification and the diversity of plants and remove these alternative learnings if there were any. In the end, it was found that students had mislearnings about the classification and the diversity of plants. The main mislearning was that students classify some of the plants they knew well in a wrong way according to the criteria which was not biological; for example, they thought fern and bryophyte were plants with seeds, fungi were plants, and the plants belonging to the family of Pinaceae did not have real leaves so they were included in the class of plants without seeds. In order to remove these mislearnings 'Porphyrios Tree', which has a structure similar to a concept map, was used. As a result, a great majority of pre-service teachers' alternative conceptions about the classification of plants were removed through this method of application.

Key words: classification, mislearnings, plants, porphyrios tree, pre-service teach-

ers.

Selami Yangin Recep Tayyip Erdogan University, Rize, Turkey
PRE-SERVICE CLASSRDIM TEACHERS' MISLEARNINGS DF CLASSIFICATION DF THE PLANT KINGDIM AND THE EFFECT DF
PORPHYRIOS TREE DN
REMUVING THEM

\section{Selami Yangin}

\section{Introduction}

Aristotles thought that a classification was possible between different and countless amount of information about beings. That is why he arranged ten categories which included all this information. These categories are quality, quantity, relatives, time, place, posture (position), state, action, affection and substance.

Substance is the unchanging aspect of objects despite the existence and change they are in. All the categories other than substance express features of physical objects that can be perceived with senses. However, all objects have substances, unchanging and imperceptible, that give the features we perceive despite all the changes they undergo.

According to Aristotles, in order to know objects individually, it is necessary to know the general concepts which define the common features of the objects. For example, if we do not know about the concept of plants, we cannot tell whether the object we see is a plant or not. That is why Aristotle states that particulars can only be possible if universals are known. Aristotles holds the view that universal concepts have also substances as individual objects do. So, there are two types of substances:

Primary substance (substance of particular): It belongs to any object and expresses the identity and the unchanging aspect of the object.

Secondary substance (substance of universal): They are the basic features particular substances share and have in common.

Primary substance is related to the extent of the term expressing the object and the secondary substance that belongs to the same object is related to the content of the term. Therefore, the relation between these two substances is also a content-extent relation. 
Porphyrios systematized Aristotle's views on substance and object in his book 'Isagoge'. He expressed the order of concepts under the title of 'Five Universals'. In this schematic classification, called Porphyrios tree, the extent and the species of an object are found when one moves from the top to the bottom, and the content and the genus of the object are found when one moves from the bottom to the top (see Figure 1 and Figure 2).

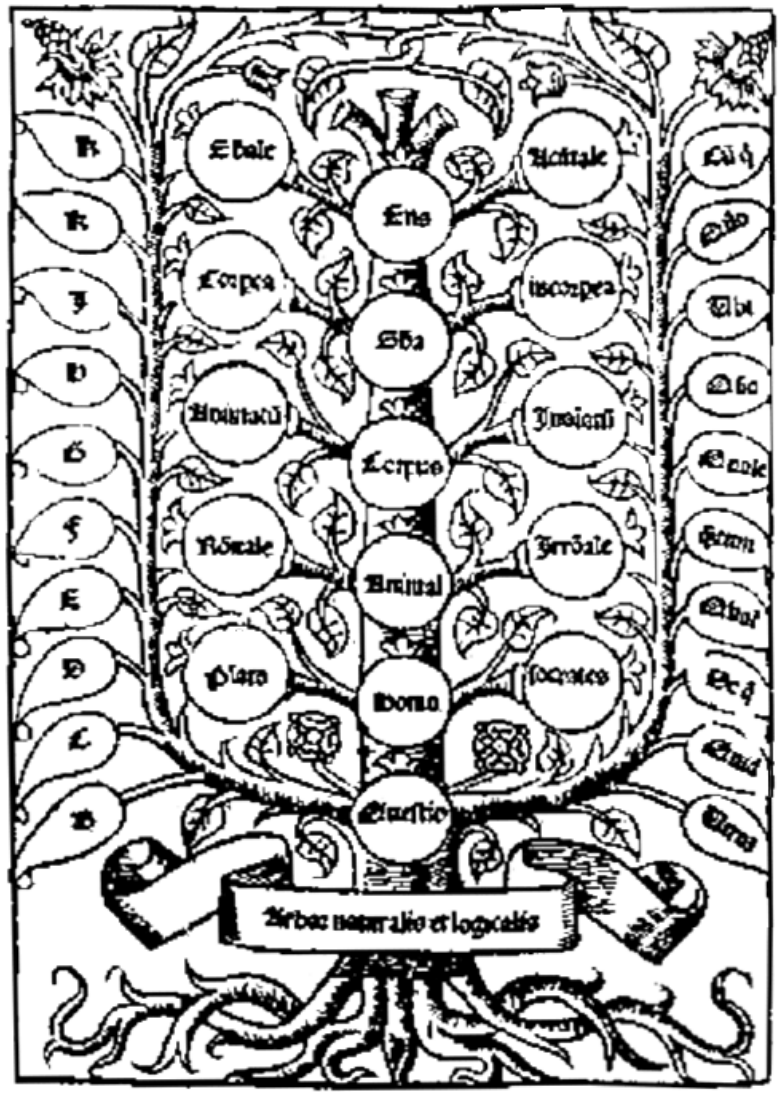

Figure 1: The basic structure of Porphyrios tree.

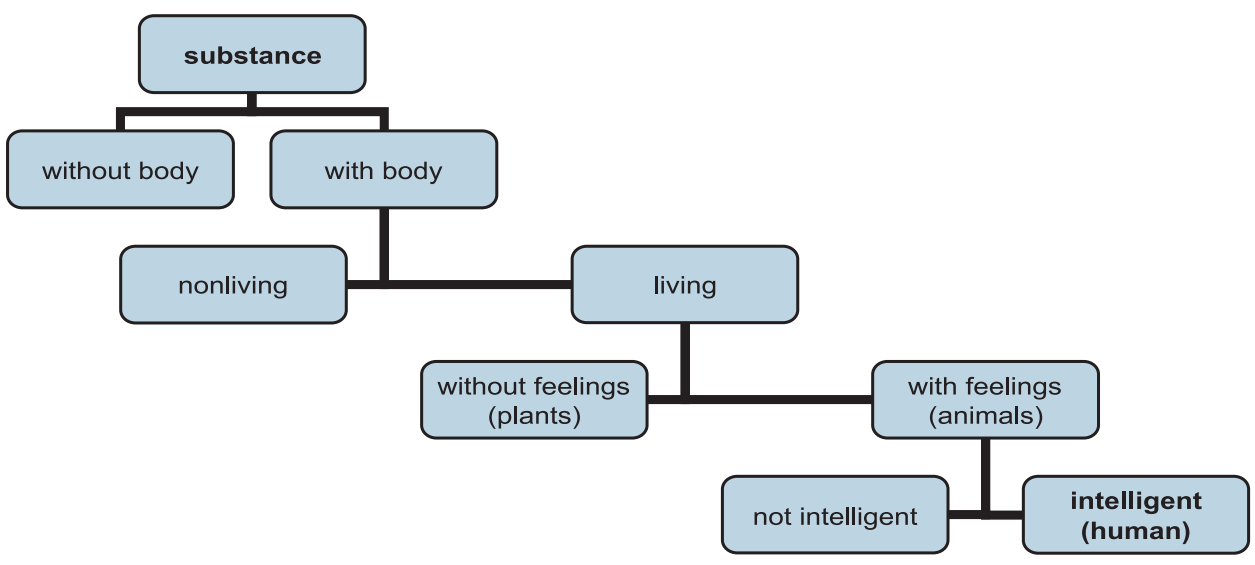

Figure 2: The relations between concepts on Porphyrios tree. 
Based on this hierarchical order, Porphyrios addressed the relations between concepts in the context of five universals (genus, species, difference, identicalness of species and relation). Five universals are as follows; genus, species, distinction, propriety and relation.

a) Genus: Among the two concepts with common features, genus is the one with more extent or it is what spesies are listed below. The more extensive one of two concepts is called genus. For example, in Porphyrios tree, 'with body' is more extensive than 'living' so 'with body' is a genus in relation to the 'living.' Genus is divided into two; close genus and far genus. Close genus is the genus which a species is directly connected to and which is just over it and the other one is called far genus. For example, the close genus of the concept 'living' is body and the far genus is substance (see Figure 3).

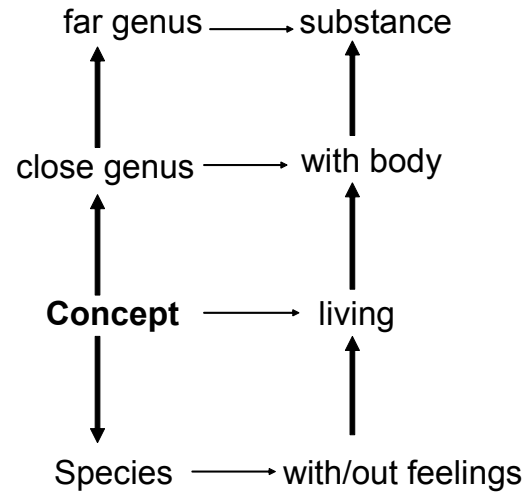

Figure 3: $\quad$ "Genus" in the context of five universals on Aristotle's views.

b) Species: Species is the term of two terms which is larger in content or what is listed under genus. For example, in the species of genus, 'oak' and 'pine' is included. Species is divided into two; Specific species and relative species. Specific species is a species which is not a genus and can not be divided into other species. For example, 'Human beings' is a specific species. Relative species is a species which can be a genus and divided into other species again. For example, 'living' is a relative species. Another example is 'music' because it can be divided into polyphonic and homophonic and be a genus. 'Cokertme', a Turkish folk song, is an example of specific species because it can not be divided into species and be a genus again.

c) Distinction: It is the basic feature of a species that shows its difference from its genus. It is the feature that seperates one term from another. For example, according to the Porphyrios tree, intelligence is the distinction that seperates humans from the species 'with feelings'. If the distinction seperates a species from its partners in its close genus, it is called close distinction. If the distinction seperates the species from its partners in far genus, it is called far distinction. For example, 'thinking' is human's close distinction and 'moving' is far distinction.

d) Propriety: It is the feature that belongs to only one species and necessarily related to the seperation. For example, culture and socialization are features to belong only to humans so their propriety.

e) Relation: It is the feature that is commonly found in a species. For example, sleeping, growing and reproduction are human being's relation because they are the features found in every species of this living being (Dogan, 1999).

From this perspective, there are two ways of forming a conceptual hierarchy or a conceptual system:

1. Rational Way:

a) Ordering all beings as genus and species of a concept from top to bottom, starting from a concept that all beings originate from, includes all beings, a concept at of the top in terms of extent and has no other concepts over. This way, as seen in Aristotle's example, is followed by 
all philosophers of ontology and metaphysics.

b) The same way is followed also in mathematics. For example in geometry, whole geometric space is designed as a space of points. Aristotles, in his own ontology, designed primary substances as unchanging units that are self-standing, identical to themselves. If the analogy is correct, the primary substances of geometry are points that are self-standing, identical to themselves, without dimensions and body. Only then, it will be possible to define'a line' as'the sum of points between two points' thus geometry is established as a deductive and discoursive system of concepts from top to bottom. Now it is possible to prove that the cross-section of a globe with a plane is a circle. In ontology, it is possible to establish a 'system of beings' or 'geometric system' because we define the top concepts, in a sense, in mathematics implicitly and determine their contents in such a way that that include all areas of subjects, that is to say a hormony is ensured for all subjects -and/or objects-. From this result, it can be readily inferred that by changing the definitions of the top concepts, other conceptual systems can be formed. It is apparent that, in the rational way, there is no place for species seperation and relation.

2. Empirical way:

The fundament of natural sciences is starting from experiments and observation. However, objects may have infinite number of properties and only some of these properties can be detected with experiment and observation. An individual form the overall concepts according to the features s/he can detect and tries to determine the inclusion (extent) and meaning (content) relationship between objects. So, natural sciences try to comprehend the features obtained through the empirical way in a conceptual order. On the other hand, even if experiment and observation show that features of objects are together, there is no rational obligation that they must coexist. Nevertheless, reaching a rational description and explanation of nature is aimed by connecting these features to each other through the rational way. In other words, what sciences perform is connecting findings obtained empirically to each other through the rational way. To this end, sciences, like in ontology and mathematics, design something such as 'atom,' 'electron', 'particle' for every object that forms the carrier and basis of those things. So, the world of all natural objects and the Universe are created from 'atoms', 'electrons' and 'particles' as all the geometric space is created from points and all beings from beings. Sciences form a deductive structure starting from genus-species and content-extent relationship. However, it remains only as an ideal for philosophy and sciences to establish a complete deductive structure because every rational structure may be shaken by new information and replaced by new rational structures. However, as it will be seen, the requirement for establishing rational structures is to create an order intertwined with concepts, all homogeneous according to subjects (Dogan, 1999).

Biology course is one of the courses that students experience difficulty with. That the course includes lots of abstract concepts may cause students have difficulty in constructing knowledge. Studies conducted in the last 15-20 years in the field of Biology teaching have shown that students have mislearnings about a lot of subjects: Cell structure (Marek, 1986), osmosis and diffusion (Zukerman, 1994; Friedler, Amir \& Tamir, 1987; Marek, Cowan \& Cavallo, 1994; Odom \& Barrow, 1995; Westbrook \& Marek, 1991), photosynthesis (Amir \& Tamir, 1994), genetics (Cavello \& Schafer, 1994; Stewart, Hafner \& Dale, 1990; Stewart \& Dale, 1989; Fisher, 1985; Clough \& Wood-Robinson, 1985; Kargbo, Hobbs \& Erickson, 1980; Brumby, 1979), growth and development (Smith \& Anderson, 1984), food-web (Griffiths \& Grant, 1985; Webb \& Boltt, 1990), ecology (Adeniyi, 1985), theory of evolution (Brumby, 1984), living and nonliving (Looft, 1974), respiration (Sander, 1993), cell metabolism (Storey, 1991), classification (Trowbridge \& Mintzes, 1988, Braund, 1998; Meir et al., 2007, Doug, 2011), mammals (Kubiatko \& Prokop, 2007), homeostasis (Westbrook \& Marek, 1992), circulatory system in humans (Arnaudin \& Mintzes, 1985; cited. Tekkaya, Capa \& Yılmaz, 2000). Research efforts that address students' understanding of classification concepts have been widely reported, especially in the United States, New Zealand and Great Britain. To date, follow-up studies in Taiwan and other Asian countries (Chunawala et al., 1996; Natarajan, 1996; Ramadas, 1996) have been lagging, in part because these concepts are often given a less prominent place in modern science. 
In today's science education, it has become very important to study the scientific correctness of students' conceptual hierarchies about science subjects and, in this context, their mislearnings because recent studies have shown that students are faced with the difficulty of perceiving concepts in many fields of science education (Dikmenli, Çardak \& Turkmen, 2002).

It is almost that conventional teaching methods and techniques are not sufficient to acquire desired achievement levels (Hestenes, 1996; cited. Bilal \& Erol, 2012). Conventional instruction, a deductive approach, offers the teacher right at the centre of the instruction process and only activates the teachers; nevertheless the students are in a role of just passive followers. During the conventional teaching, the topic is generally explained initially and then some quantitative problems are solved by the instructor/teacher and in some cases additional problems are given students to be solved as homework. The course of action supported by some close ended experimental activities. The conventional instructing does generally not take into account any mislearnings and considers that the students learn easily by means of problem solving, however many researchers have shown that the reality is quite different (Lattery, 2007; cited. Bilal \& Erol, 2012 ).

Some scientifically incorrect knowledge students develop specific to themselves and expressed as naive theories, misconceptions and alternative conceptions create great obstacles in the process of learning. According to the findings from studies conducted so far, students develop this complicated and incorrect knowledge through their interpretations during the first periods of their school years or some inconsistent explanations made inside or outside their schools (Bell, 1981; Driver, 1981; Bell \& Barker, 1982; Gilbert, Osborne \& Fensham, 1982). Misconceptions appear before us as a factor that hinders meaningful learning because they not only prevent the reconstruction of newly learned information but also damage the integrity of meaning (Bahar, 2003).

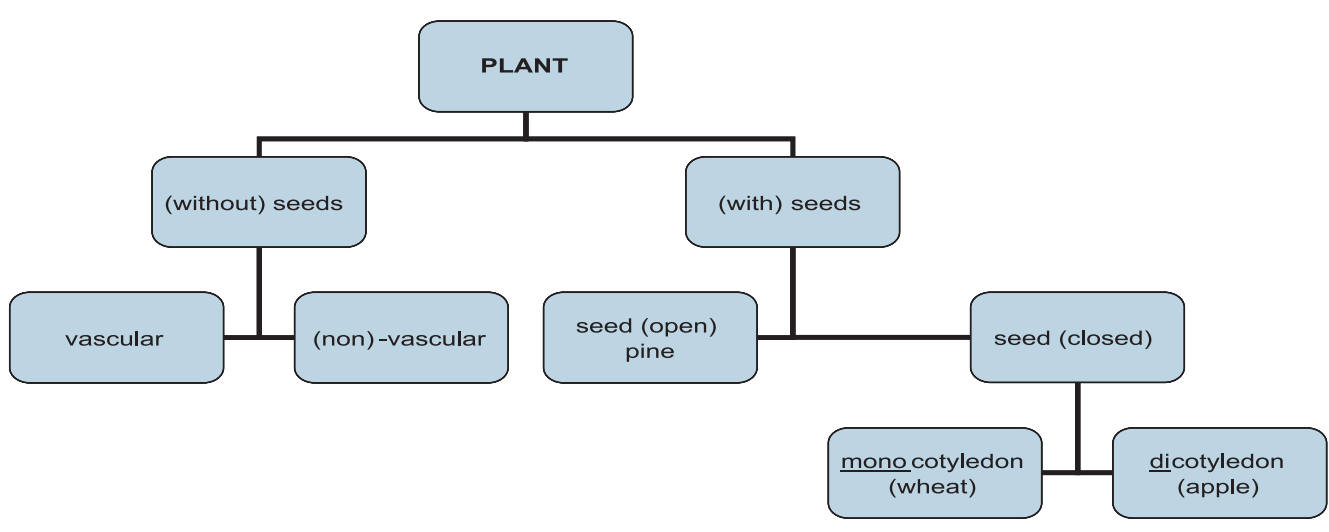

Figure 4: A simple Porphyrios tree formed about the classification of plants.

\section{Problem of Research}

In this context, the problem of the study was designed as 'Can the application of Porphyrios tree technique remove students' mislearnings about the classification of plants if there are any'. It increases the significance of the study that no studies were found about the subject in this field. It is supposed that, in addition to the teaching materials (such as concept maps, conceptual change texts, concept caricatures) frequently used to find out or remove misconceptions, the results that will be obtained through the application of Porphyrios tree, not frequently used in learning settings, may offer important explanations to the field. 
In this study, an application technique similar to the concept map, mentioned as Porphyrios tree, was used. There was no scientific study on this topic. A concept map is a two-dimensional graphical teaching material that shows the relation between the main concept and sub-concepts as propositions. With this material, students have to connect the relation between the two concepts by finding an appropriate action. On the other hand, in Porphyrios tree, they relate concepts from top to bottom or from bottom to top within the content-extent relation in the form of universals instead of relating one concept to another in a plain way (Figure 4). In this respect, it may prevent the formation of incorrect systematic schemas by putting in order a lot of features, common or not, related to a concept. It may construct scientifically correct conceptual hierarchies.

\section{Methodology of Research}

In this study, clinical interview method which is mentioned to be one of the qualitative research designs was used. Clinical interview was first used by Piaget for psychological researches. Piaget states that children's mistakes give significant clues about their nature of thoughts. He developed clinical interview, which is a flexible question asking method, to discover the richness in students' thoughts, catching their basic activities and evaluating cognitive skills. While explaining students' cognition with clinical interviews, not only the theory is put forward but also the social structure in which learning takes place can be explained.

\section{Sample}

The sample of this study consists of 54 students having education in Department of Primary School Classroom Teaching in Recep Tayyip Erdoğan University Faculty of Education in Fall Semester of 2011-2012 academic year. These students were divided into three groups each of which consists of 18 individuals. The students involved in these groups were randomly sampled among the class. The reason for separating of fifty-four students into three groups is belief that this technique can not be successful in large groups. The model of the experiment-control group was not created although these groups in this situation. Because the purpose of this study, the experimental and control figured (multimodal) group is not dealt with a purpose.

\section{Method of the Study}

In order to detect student misconceptions, clinical interviews were conducted. In clinical interview technique, whether the student learn the concept can be investigated deeply while he/she is being interviewed about a situation or an event. In some cases, students are asked to define a concept and in addition they are expected to answer and explain why they reach that idea. The explanations by students reveal students' understanding criteria. In these interviews the exchange starts with starter questions and by making students focus on the topic or the concept which will soon be given. Then it goes on with questions about a range of pictures (White \& Gunstone, 1992).

In the study, experiment-control design was not applied because the studies conducted in three groups were evaluated holistically, alternative conceptions only in application group were determined and their removal was aimed. The obtained data (qualitative data in interviews) was digitized. In this study, a pilot study was conducted in another group which was similar to the sample before passing to main application. For the validity of the applications to be used in the study, expert views related to the field were taken. Application steps were realized in two phases.

In the first step, each student was interviewed for almost 20 minutes in an appropriate environment in a way that was consistent with the goal. During the interviews, questions and answers were simultenaously noted by taking voice record. The interviews were carried out in two steps.

First step: In this step, coloured photos of mushrooms and 15 plant samples consisting of plants 
with seeds and plants without seeds were chosen. These consisted of photographs of mushrooms and plants without seeds (non-vascular <algae, bryophyte $>$ and vascular <fern $>$, lungwort), plants with seeds (gymnosperm < pine, fir, spruce>, among angiosperm plants monocotyledons < wheat, corn> and dicotyledons <apple, apricot, horsebean, pea, peanut $>$. During the interviews, these photos were mixed on a table and the students were asked to classify these plants firstly as plants with seeds and plants without seeds and then they were asked to classify the plants with seeds as monocotyledons and dicotyledons, and the plants without seed as vascular and non-vascular. After that, for each group separately, the students were asked such questions as "Why is this plant involved in this group?", "Are there other reasons?" and "Why didn't you put these samples in any groups?".

Second Step: In this step, the photographs used in the first step were mixed again on the table and the students were asked to distinguish "plants" and "non-plants". Later, they were asked "Why are these plants?" or "Why aren't these plants?". In addition to this, Porphyrios tree was applied. The application took almost two hours for each group. During the application the students were wanted to form individual and group trees related to each plant sample.

\section{Data Analysis}

The data obtained in this study was analyzed with qualitative data analysis method. The answers given by the participants were categorized by determining the points they agreed and the points they disagreed (Yin, 1994). The related expressions were put together under the same title (Cohen \& Manion, 1989; Goldin, 1998). By this way, the data of the study were analyzed regarding to the main research question and by being grouped with respect to similarities. Accordingly, the answers to the questions were categorized. In evaluation of data, frequency values and \% (percent) expressions were used (Trowbridge \& Mintzes, 1985; Chen \& Ku, 1998) and misclassifications exceeding \% 15 were accepted to be meaningful (Braund, 1991).

\section{Results of Research}

In this study designed to remove and detect misconceptions of university students about the topic "classification of plants" in systematic unit, the data obtained by clinical interviews were interpreted with qualitative data analysis method. The data were classified as 1 st step-application and 2nd stepapplication and presented in this section.

\section{Findings Related to the 1st Step}

During the first step of the interview, in order to explore students' views on the classification of plants, students were shown 15 mixed photographs including samples of algae, bryophytes, fern, lungwort, lycopodium clavatum, pine, fir tree, spruce, wheat, corn, apple, apricot, horsebean, peas, peanuts and a photograph of a mushroom. After that, students were told to classify these plants as plants with seeds and plants without seed, and then classify plants with seeds as monocotyledons and dicotyledons, and plants without seeds as vascular or non-vascular plants. The results are shown in Table 1. Misclassifications were found in all plant species and in all three groups of students. The rate of misclassifications in some plant samples (fern and bryophytes) and the sample of mushroom was observed to reach $100 \%$.

\section{Mislearnings about Plants without Seeds}

As seen in Table 1, it was observed that some students in each group included samples such as pine, fir tree and spruce in the class of plants without seeds. Especially, the belief that pine is a plant without seeds was a more widespread mislearning among students. It becomes apparent that students defined 'pine' as a plant without seeds because of its great size, woody structure, not having flowers made up of colourful petals and sepals, being in a spiny structure and a fern-like morphology and its habitat. Also, many of the students who included mushrooms into the plant kingdom discussed this kingdom in the 
plants without seeds. Students' concept of plants without seeds was found as 'plants with or without a big trunk, hard, spiny, living in various habitats, not having a colourful flower thus not having seeds'.

\section{Mislearnings about Plants with Seeds}

As seen in Table 1, it was understood that that a few students from each group included plants without seeds such as lycopodium clavatum and lungwort in the class of plants with seeds. In addition, some of the students who included mushrooms in the kingdom of plants also discussed this kingdom in plants with seeds. It was found that students' conception of plants with seeds was as, 'plants with a big or a small trunk, circular or oval plump leaves, living in various habitats and having colourful flowers thus seeds'.

Table 1. Frequency and Percentage Values of Students' Answers about the Classification of Plants Before the Application of Porphyrios Tree.

\begin{tabular}{|c|c|c|c|c|c|c|c|c|c|c|c|c|c|c|}
\hline \multirow{2}{*}{ Groups } & & & \multirow[b]{2}{*}{ Samples } & \multirow[b]{2}{*}{$\mathrm{N}$} & \multicolumn{10}{|c|}{ Characteristics } \\
\hline & & & & & $\begin{array}{c}\text { without } \\
\text { seed } \\
f(\%)\end{array}$ & $\begin{array}{l}\text { with seed } \\
f(\%)\end{array}$ & $\begin{array}{c}\text { vascular } \\
f(\%)\end{array}$ & $\begin{array}{c}\text { non- } \\
\text { vascular } \\
f(\%)\end{array}$ & $\begin{array}{c}\text { gymnosperm } \\
f(\%)\end{array}$ & $\begin{array}{c}\text { angiosperm } \\
f(\%)\end{array}$ & $\begin{array}{c}\text { monocotyl } \\
f(\%)\end{array}$ & $\begin{array}{l}\text { dicotyl } \\
f(\%)\end{array}$ & $\begin{array}{l}\text { plant } \\
f(\%)\end{array}$ & $\begin{array}{l}\text { not a } \\
\text { plant } \\
f(\%)\end{array}$ \\
\hline \multirow{5}{*}{$\begin{array}{l}\text { Seedless } \\
\text { plants }\end{array}$} & \multirow{4}{*}{\multicolumn{2}{|c|}{ Non-Vascular }} & algae & 54 & $\begin{array}{c}54 \\
(100)\end{array}$ & - & $\begin{array}{c}35 \\
(64,8) \\
\end{array}$ & $\begin{array}{c}19 \\
(35,2)\end{array}$ & - & - & - & - & $\begin{array}{c}46 \\
(85,2)\end{array}$ & $\begin{array}{c}8 \\
(14,8)\end{array}$ \\
\hline & & & bryophyte & 54 & $\begin{array}{c}49 \\
(90,8)\end{array}$ & $\begin{array}{c}5 \\
(9,2)\end{array}$ & $\begin{array}{c}14 \\
(25,9)\end{array}$ & $\begin{array}{c}40 \\
(74,1)\end{array}$ & $\begin{array}{c}49 \\
(90,8)\end{array}$ & $\begin{array}{c}5 \\
(9,2)\end{array}$ & $\begin{array}{c}30 \\
(55,6)\end{array}$ & $\begin{array}{c}24 \\
(44,4)\end{array}$ & $\begin{array}{c}49 \\
(90,8)\end{array}$ & $\begin{array}{c}5 \\
(9,2)\end{array}$ \\
\hline & & & lungwort & 54 & $\begin{array}{c}43 \\
(79,7)\end{array}$ & $\begin{array}{c}11 \\
(20,3)\end{array}$ & $\begin{array}{c}38 \\
(70,4)\end{array}$ & $\begin{array}{c}16 \\
(29,6)\end{array}$ & $\begin{array}{c}40 \\
(74,1)\end{array}$ & $\begin{array}{c}14 \\
(25,9)\end{array}$ & $\begin{array}{c}38 \\
(70,4)\end{array}$ & $\begin{array}{c}16 \\
(29,6)\end{array}$ & $\begin{array}{c}54 \\
(100)\end{array}$ & - \\
\hline & & & $\begin{array}{l}\text { lycopodium } \\
\text { clavatum }\end{array}$ & 54 & $\begin{array}{c}40 \\
(74,1)\end{array}$ & $\begin{array}{c}14 \\
(25,9)\end{array}$ & $\begin{array}{c}40 \\
(74,1)\end{array}$ & $\begin{array}{c}14 \\
(25,9)\end{array}$ & $\begin{array}{c}40 \\
(74,1)\end{array}$ & $\begin{array}{c}14 \\
(25,9)\end{array}$ & $\begin{array}{c}40 \\
(74,1)\end{array}$ & $\begin{array}{c}14 \\
(25,9)\end{array}$ & $\begin{array}{c}54 \\
(100)\end{array}$ & - \\
\hline & \multicolumn{2}{|c|}{ Vascular } & fern & 54 & $\begin{array}{c}49 \\
(90,8)\end{array}$ & $\begin{array}{c}5 \\
(9,2) \\
\end{array}$ & $\begin{array}{c}40 \\
(74,1)\end{array}$ & $\begin{array}{c}14 \\
(25,9)\end{array}$ & $\begin{array}{c}49 \\
(90,8)\end{array}$ & $\begin{array}{c}5 \\
(9,2) \\
\end{array}$ & $\begin{array}{c}43 \\
(79,7)\end{array}$ & $\begin{array}{c}11 \\
(20,3)\end{array}$ & $\begin{array}{c}54 \\
(100)\end{array}$ & - \\
\hline \multirow{10}{*}{$\begin{array}{l}\text { Seed } \\
\text { plants }\end{array}$} & \multirow{3}{*}{\multicolumn{2}{|c|}{ Gymnosperm }} & pine & 54 & $\begin{array}{c}30 \\
(55,6)\end{array}$ & $\begin{array}{c}24 \\
(44,4)\end{array}$ & $\begin{array}{c}35 \\
(64,8)\end{array}$ & $\begin{array}{c}19 \\
(35,2)\end{array}$ & $\begin{array}{c}40 \\
(74,1)\end{array}$ & $\begin{array}{c}14 \\
(25,9)\end{array}$ & $\begin{array}{c}43 \\
(79,7)\end{array}$ & $\begin{array}{c}11 \\
(20,3)\end{array}$ & $\begin{array}{c}54 \\
(100)\end{array}$ & - \\
\hline & & & firtree & 54 & $\begin{array}{c}24 \\
(44,4)\end{array}$ & $\begin{array}{c}30 \\
(55,6)\end{array}$ & $\begin{array}{c}32 \\
(59,3)\end{array}$ & $\begin{array}{c}22 \\
(40,7)\end{array}$ & $\begin{array}{c}43 \\
(79,7)\end{array}$ & $\begin{array}{c}11 \\
(20,3)\end{array}$ & $\begin{array}{c}46 \\
(85,2)\end{array}$ & $\begin{array}{c}8 \\
(14,8)\end{array}$ & $\begin{array}{c}54 \\
(100)\end{array}$ & - \\
\hline & & & spruce & 54 & $\begin{array}{c}22 \\
(40,7)\end{array}$ & $\begin{array}{c}32 \\
(59,3)\end{array}$ & $\begin{array}{c}35 \\
(64,8)\end{array}$ & $\begin{array}{c}19 \\
(35,2)\end{array}$ & $\begin{array}{c}43 \\
(79,7)\end{array}$ & $\begin{array}{c}11 \\
(20,3)\end{array}$ & $\begin{array}{c}49 \\
(90,8)\end{array}$ & $\begin{array}{c}5 \\
(9,2)\end{array}$ & $\begin{array}{c}54 \\
(100)\end{array}$ & - \\
\hline & \multirow{2}{*}{\multicolumn{2}{|c|}{ Monocotyl }} & wheat & 54 & $\begin{array}{c}5 \\
(9,2)\end{array}$ & $\begin{array}{c}49 \\
(90,8)\end{array}$ & $\begin{array}{c}11 \\
(20,3)\end{array}$ & $\begin{array}{c}43 \\
(79,7) \\
\end{array}$ & $\begin{array}{c}5 \\
(9,2) \\
\end{array}$ & $\begin{array}{c}49 \\
(90,8)\end{array}$ & $\begin{array}{c}49 \\
(90,8)\end{array}$ & $\begin{array}{c}5 \\
(9,2) \\
\end{array}$ & $\begin{array}{c}54 \\
(100) \\
\end{array}$ & - \\
\hline & & & corn & 54 & $\begin{array}{c}(1,2) \\
8 \\
(14,8)\end{array}$ & $\begin{array}{c}46 \\
(85,2)\end{array}$ & $\begin{array}{c}\frac{1}{16} \\
(29,6)\end{array}$ & $\begin{array}{c}38 \\
(70,4)\end{array}$ & $\begin{array}{c}8,2) \\
(14,8)\end{array}$ & $\begin{array}{c}46 \\
(85,2)\end{array}$ & $\begin{array}{c}46 \\
(85,2)\end{array}$ & $\begin{array}{c}(1,2) \\
8 \\
(14,8)\end{array}$ & $\begin{array}{c}54 \\
(100)\end{array}$ & - \\
\hline & \multirow{5}{*}{\multicolumn{2}{|c|}{ Angiosperm }} & apple & 54 & - & $\begin{array}{c}54 \\
(100) \\
\end{array}$ & - & - & $\begin{array}{c}16 \\
(29,6) \\
\end{array}$ & $\begin{array}{c}38 \\
(70,4)\end{array}$ & $\begin{array}{c}22 \\
(40,7)\end{array}$ & $\begin{array}{c}32 \\
(59,3)\end{array}$ & $\begin{array}{c}54 \\
(100)\end{array}$ & - \\
\hline & & & apricot & 54 & - & $\begin{array}{c}54 \\
(100)\end{array}$ & - & - & $\begin{array}{c}5 \\
5 \\
(9,2)\end{array}$ & $\begin{array}{c}49 \\
(90,8)\end{array}$ & $\begin{array}{c}38 \\
(70,4)\end{array}$ & $\begin{array}{c}16 \\
(29,6)\end{array}$ & $\begin{array}{c}54 \\
(100)\end{array}$ & - \\
\hline & & & horsebean & 54 & - & $\begin{array}{c}54 \\
(100)\end{array}$ & - & - & $\begin{array}{c}5 \\
(9,2)\end{array}$ & $\begin{array}{c}49 \\
(90,8)\end{array}$ & $\begin{array}{c}5 \\
(9,2)\end{array}$ & $\begin{array}{c}49 \\
(90,8)\end{array}$ & $\begin{array}{c}54 \\
(100)\end{array}$ & - \\
\hline & & & pea & 54 & - & $\begin{array}{c}54 \\
(100)\end{array}$ & - & - & $\begin{array}{c}5 \\
(9,2)\end{array}$ & $\begin{array}{c}49 \\
(90,8)\end{array}$ & $\begin{array}{c}5 \\
(9,2) \\
\end{array}$ & $\begin{array}{c}49 \\
(90,8)\end{array}$ & $\begin{array}{c}54 \\
(100)\end{array}$ & - \\
\hline & & & peanut & 54 & $\begin{array}{c}5 \\
(9,2)\end{array}$ & $\begin{array}{c}49 \\
(90,8)\end{array}$ & & & - & $\begin{array}{c}54 \\
(100)\end{array}$ & $\begin{array}{c}5 \\
(9,2)\end{array}$ & $\begin{array}{c}49 \\
(90,8)\end{array}$ & $\begin{array}{c}54 \\
(100)\end{array}$ & - \\
\hline \multicolumn{3}{|l|}{ Fungi } & mushroom & 54 & $\begin{array}{c}49 \\
(90,8)\end{array}$ & $\begin{array}{c}5 \\
(9,2)\end{array}$ & $\begin{array}{c}5 \\
(9,2)\end{array}$ & $\begin{array}{c}49 \\
(90,8)\end{array}$ & $\begin{array}{c}49 \\
(90,8)\end{array}$ & $\begin{array}{c}5 \\
(9,2)\end{array}$ & $\begin{array}{c}46 \\
(85,2)\end{array}$ & $\begin{array}{c}8 \\
(14,8)\end{array}$ & $\begin{array}{c}14 \\
(25,9)\end{array}$ & $\begin{array}{c}40 \\
(74,1)\end{array}$ \\
\hline
\end{tabular}

\section{Mislearnings about Non-vascular Plants}

Students were engaged in various alternative conceptions about the classification of non-vascular plants without seeds, which we include in the phylum of plants without seeds. In the first step, students were told to decide whether the sample in the photograph was a plant, and then asked to state whether this plant was a plant with or without seeds. After this step, students who decided that this plant was, for example, a plant without seed were asked to think about whether this plant was a vascular or nonvascular plant. Some of the students stated that plants wihout seeds such as algae, lungwort, lycopodium clavatum and fern were non-vascular. Also, samples that should have been included in plants with seeds but addressed by students as a part of plants without seeds, such as pine, fir tree, spruce, wheat, corn and peanut were shown in the class of non-vascular plants without seeds. It was found out that students' conception of non-vascular plants without seeds was as, 'plants that do not have thin-long lines when examined with a microscope or with naked eye, without any reproductive organs differentiation such as flowers, fruit, and seeds, and sometimes without leaves'. 


\section{Mislearnings about Vascular Plants}

Samples such as pine, fir tree, spruce, wheat and corn, which should have been included in plants with seeds but included in plants without seeds by students were shown in the class of vascular plants without seeds. It was found out that students' conception of vascular plants without seeds was as, 'plants that have thin-long lines or vessels when examined with a microscope or with naked eye, with reproductive organs such as flowers and fruits, and plants that have noticable root, trunk, leaves differentiations'.

\section{Mislearnings about Gymnosperms}

Students had various alternative conceptions about the classification of plants with open seeds, also known as "Gymnospermae" and included in the phylum of plants with seeds. In this step, students ,with a percentage of $45 \%$ and $55 \%$, discussed gymnosperms, such as pine, fir tree and spruce, in plants without seeds. On the other hand, $75-80 \%$ of students stated that these samples were gymnosperms. Students' definition of the concept of gymnosperms was found as'plants with seeds in the open unprotected, without any protective coat, with cone and not showing a noticable flower development'.

\section{Mislearnings about Angiosperms}

Students offered alternative definitions of the class of angiosperms, which is included in the phylum of plants with seeds. In this step, students included samples such as corn and apple in gymnosperms. They all considered peanut as an angiosperm. On the other hand, it was observed that there were some students who considered samples such as wheat, apricot, horsebean and pea as partly gymnosperms. Accordingly, students' definition of the concept of angiosperms was found as 'plants with seeds in the open or no seeds, sometimes having a plump protective coat over their seeds, and showing a noticable flower development'.

\section{Mislearnings about Monocotyledons}

Students also offered alternative definitions in the classification of monocotyledons in the class of angiosperms. In this step, students considered samples such as apricot and apple as monocotyledons. In addition, some students were seen to consider corn as dicotyledon even though it is monocotyledon. So, students'definition of the concept of monocotyledons was found as 'flowering plants often with a tree-like appearance, in a fruit structure, having a plump protective coat'.

\section{Mislearnings about Dicotyledons}

Students offered various definitions in dicotyledons, which are in the class of angiosperms as well. In this step, they considered corn as a dicotyledon. In addition, it was found that some students thought samples such as apple and apricot as monocotyledons even though they are dicotyledons. So, students'definition of the concept of dicotyledons was found as 'plants widely known by people as vegetables, mostly with a herbal appearance, containing a lot of seeds in themselves'.

\section{Findings Related to the 2nd Step}

During the second step, the study was carried out by applying the Porphyrios tree technique about 
the subject in order to correct students' alternative conceptions identified about the classification of plants. The results related to this part of the study, which was conducted experimentally, were shown in Table 2.

Table 2. Frequency and Percentage Values of Students' Answers about the Classification of Plants After the Application of Porphyrios Tree.

\begin{tabular}{|c|c|c|c|c|c|c|c|c|c|c|c|c|c|c|}
\hline \multirow[b]{2}{*}{ Groups } & & & \multirow[b]{2}{*}{ Samples } & \multirow[b]{2}{*}{$\mathbf{N}$} & \multicolumn{10}{|c|}{ Characteristics } \\
\hline & & & & & $\begin{array}{c}\text { without } \\
\text { seed } \\
f(\%)\end{array}$ & $\begin{array}{c}\text { with seed } \\
f(\%)\end{array}$ & $\begin{array}{c}\text { vascular } \\
f(\%)\end{array}$ & $\begin{array}{c}\text { non- } \\
\text { vascular } \\
f(\%)\end{array}$ & $\begin{array}{c}\text { gymnosperm } \\
f(\%)\end{array}$ & $\begin{array}{c}\text { angiosperm } \\
f(\%)\end{array}$ & $\begin{array}{c}\text { monocotyl } \\
f(\%)\end{array}$ & $\begin{array}{l}\text { dicotyl } \\
f(\%)\end{array}$ & $\begin{array}{l}\text { plant } \\
f(\%)\end{array}$ & $\begin{array}{l}\text { not a } \\
\text { plant } \\
f(\%)\end{array}$ \\
\hline \multirow{5}{*}{$\begin{array}{l}\text { Seedless } \\
\text { plants }\end{array}$} & \multirow{4}{*}{\multicolumn{2}{|c|}{ Non-Vascular }} & algae & 54 & $\begin{array}{c}54 \\
(100)\end{array}$ & - & $\begin{array}{c}8 \\
(14,8)\end{array}$ & $\begin{array}{c}46 \\
(85,2)\end{array}$ & - & - & - & - & $\begin{array}{c}51 \\
(94,4)\end{array}$ & $\begin{array}{c}3 \\
(5,6)\end{array}$ \\
\hline & & & bryophyte & 54 & $\begin{array}{c}51 \\
(94,4) \\
\end{array}$ & $\begin{array}{c}3 \\
(5,6)\end{array}$ & $\begin{array}{c}5 \\
(9,2) \\
\end{array}$ & $\begin{array}{c}49 \\
(90,8)\end{array}$ & - & - & $\begin{array}{c}3 \\
(5,6)\end{array}$ & - & $\begin{array}{c}54 \\
(100) \\
\end{array}$ & - \\
\hline & & & lungwort & 54 & $\begin{array}{c}49 \\
(90,8)\end{array}$ & $\begin{array}{c}5 \\
(9,2) \\
\end{array}$ & $\begin{array}{c}11 \\
(20,3)\end{array}$ & $\begin{array}{c}43 \\
(79,7)\end{array}$ & - & - & $\begin{array}{c}3 \\
(5,6)\end{array}$ & - & $\begin{array}{c}54 \\
(100) \\
\end{array}$ & - \\
\hline & & & $\begin{array}{l}\text { lycopodium } \\
\text { clavatum }\end{array}$ & 54 & $\begin{array}{c}49 \\
(90,8)\end{array}$ & $\begin{array}{c}5 \\
(9,2)\end{array}$ & $\begin{array}{c}11 \\
(20,3)\end{array}$ & $\begin{array}{c}43 \\
(79,7)\end{array}$ & - & - & $\begin{array}{c}3 \\
(5,6)\end{array}$ & - & $\begin{array}{c}54 \\
(100)\end{array}$ & - \\
\hline & \multicolumn{2}{|c|}{ Vascular } & fern & 54 & $\begin{array}{c}51 \\
(94,4)\end{array}$ & $\begin{array}{c}3 \\
(5,6)\end{array}$ & $\begin{array}{c}51 \\
(94,4)\end{array}$ & $\begin{array}{c}3 \\
(5,6)\end{array}$ & - & - & $\begin{array}{c}5 \\
(9,2)\end{array}$ & - & $\begin{array}{c}54 \\
(100)\end{array}$ & - \\
\hline \multirow{10}{*}{$\begin{array}{l}\text { Seed } \\
\text { plants }\end{array}$} & \multirow{3}{*}{\multicolumn{2}{|c|}{ Gymnosperm }} & pine & 54 & $\begin{array}{c}8 \\
(14,8)\end{array}$ & $\begin{array}{c}46 \\
(85,2)\end{array}$ & $\begin{array}{c}3 \\
(5,6)\end{array}$ & - & $\begin{array}{c}51 \\
(94,4) \\
\end{array}$ & $\begin{array}{c}3 \\
(5,6) \\
\end{array}$ & $\begin{array}{c}5 \\
(9,2)\end{array}$ & - & $\begin{array}{c}54 \\
(100)\end{array}$ & - \\
\hline & & & firtree & 54 & $\begin{array}{c}5 \\
(9,2)\end{array}$ & $\begin{array}{c}49 \\
(90,8)\end{array}$ & $\begin{array}{c}3 \\
(5,6)\end{array}$ & - & $\begin{array}{c}54 \\
(100)\end{array}$ & - & $\begin{array}{c}5 \\
(9,2)\end{array}$ & - & $\begin{array}{c}54 \\
(100)\end{array}$ & - \\
\hline & & & spruce & 54 & $\begin{array}{c}3 \\
(5,6) \\
\end{array}$ & $\begin{array}{c}51 \\
(94,4) \\
\end{array}$ & $\begin{array}{c}3 \\
(5,6) \\
\end{array}$ & - & $\begin{array}{c}51 \\
(94,4) \\
\end{array}$ & $\begin{array}{c}3 \\
(5,6) \\
\end{array}$ & $\begin{array}{c}5 \\
(9,2) \\
\end{array}$ & - & $\begin{array}{c}54 \\
(100) \\
\end{array}$ & - \\
\hline & \multirow{2}{*}{\multicolumn{2}{|c|}{ Monocotyl }} & wheat & 54 & $\begin{array}{c}5 \\
(9,2) \\
\end{array}$ & $\begin{array}{c}49 \\
(90,8)\end{array}$ & $\begin{array}{c}3 \\
(5,6) \\
\end{array}$ & - & - & $\begin{array}{c}54 \\
(100) \\
\end{array}$ & $\begin{array}{c}51 \\
(94,4) \\
\end{array}$ & $\begin{array}{c}3 \\
(5,6)\end{array}$ & $\begin{array}{c}54 \\
(100) \\
\end{array}$ & - \\
\hline & & & corn & 54 & $\begin{array}{c}3 \\
(5,6)\end{array}$ & $\begin{array}{c}51 \\
(94,4)\end{array}$ & $\begin{array}{c}3 \\
(5,6)\end{array}$ & - & - & $\begin{array}{c}54 \\
(100)\end{array}$ & $\begin{array}{c}51 \\
(94,4)\end{array}$ & $\begin{array}{c}3 \\
(5,6)\end{array}$ & $\begin{array}{c}54 \\
(100)\end{array}$ & - \\
\hline & \multirow{5}{*}{\multicolumn{2}{|c|}{ Angiosperm }} & apple & 54 & - & $\begin{array}{c}54 \\
(100) \\
\end{array}$ & - & - & - & $\begin{array}{c}54 \\
(100) \\
\end{array}$ & $\begin{array}{c}5 \\
(9,2) \\
\end{array}$ & $\begin{array}{c}49 \\
(90,8)\end{array}$ & $\begin{array}{c}54 \\
(100) \\
\end{array}$ & - \\
\hline & & & apricot & 54 & - & $\begin{array}{c}54 \\
(100)\end{array}$ & - & - & - & $\begin{array}{c}54 \\
(100) \\
\end{array}$ & $\begin{array}{c}8 \\
(14,8)\end{array}$ & $\begin{array}{c}46 \\
(85,2)\end{array}$ & $\begin{array}{c}54 \\
(100)\end{array}$ & - \\
\hline & & & horsebean & 54 & - & $\begin{array}{c}54 \\
(100)\end{array}$ & - & - & - & $\begin{array}{c}54 \\
(100)\end{array}$ & $\begin{array}{c}3 \\
(5,6)\end{array}$ & $\begin{array}{c}51 \\
(94,4)\end{array}$ & $\begin{array}{c}54 \\
(100)\end{array}$ & - \\
\hline & & & pea & 54 & - & $\begin{array}{c}54 \\
(100)\end{array}$ & - & - & - & $\begin{array}{c}54 \\
(100) \\
\end{array}$ & $\begin{array}{c}3 \\
(5,6)\end{array}$ & $\begin{array}{c}51 \\
(94,4)\end{array}$ & $\begin{array}{c}54 \\
(100) \\
\end{array}$ & - \\
\hline & & & peanut & 54 & - & $\begin{array}{c}54 \\
(100)\end{array}$ & - & - & - & $\begin{array}{c}54 \\
(100)\end{array}$ & $\begin{array}{c}3 \\
(5,6)\end{array}$ & $\begin{array}{c}51 \\
(94,4)\end{array}$ & $\begin{array}{c}54 \\
(100)\end{array}$ & - \\
\hline \multicolumn{3}{|l|}{ Fungi } & mushroom & 54 & $\begin{array}{c}3 \\
(5,6) \\
\end{array}$ & - & - & $3(5,6)$ & - & - & $\begin{array}{c}3 \\
(5,6)\end{array}$ & - & $\begin{array}{c}3 \\
(5,6) \\
\end{array}$ & $\begin{array}{c}51 \\
(94,4) \\
\end{array}$ \\
\hline
\end{tabular}

\section{Discussion}

This research is important because it examines the conceptual understandings between student teachers' about the classification and diversity of plants. This study was conducted through one-to-one interviews with 54 1st grade students having education in the Department of Classroom Teaching and attending General Biology lesson for the pupose of determining and removing alternative learnings about the classification and diversity of plants. At the end of the first step of the study, it was found that the university students in the Department of Primary Education Classroom Teaching had unscientific alternative conceptions about the classification of plants. These views, which lead students to misconceptions, are usually developed during the first years of education and continue, as it is seen, in the following years. However, it may not be possible to offer a certain cause that is active in the formation of these misconceptions because there are a lot of living and non-living elements which affect learning in the education system. A combination of these elements may be said to affect learning on the part of individuals in a positive or a negative way. Up to now, an increasing number of studies are being conducted on alternative learnings. In several studies conducted on the classification of living things, researchers state that students misclassify samples of living things into the classes they do not belong (Bell, 1981; Bell \& Barker, 1982; Braund, 1991; Chen \& Ku, 1998; Trowbridge \& Mintzes, 1985, 1988; Kubiatko \& Prokop, 2007). The similarity between our findings and the findings of similar previous studies reveals that students may have similar misconceptions. The reason for students from different educational backgrounds, living in different countries and of different ages have similar misconceptions may be the similar experiences they have in their daily lives. The study of Natarajan et al. (2002) revealed that students' ideas about plants were effected by physical 
and social settings and by textbooks. Everyday use of, and interactions with, plants and plant products had a greater influence on students' ideas about plants.

The findings obtained in the first step of the study are not contradictory to the findings of other studies in the field but supportive of them. The application including the second step of the study and conducted in an experimental dimension was based on the Porphyrios tree technique. This technique presents a structure and procedure very similar to a conceptual map. Theoretical explanations are still inadequate about this technique, which enables students to produce simultaneous ideas about a subject both at general and specific levels.

The aim in this study was determine whether the alternative learnings that emerged in the first step were removed as a result of studies conducted with the students. In the lessons performed in three groups, changes were observed on the part of individuals in each group, mostly in a positive way. In addition, students who performed systematically correct classifications made explanations based on the Porphyrios tree. Thanks to the Porphyrios trees prepared either individually or in groups, students visualized and systematized plants. In other words, students performed mostly correct and exact classifications with Porphyrios trees, which are two dimensional visual-graphical materials. Students, who had difficulties in the first step especially in the points of plants with seeds-plants without seeds, vascular-nonvascular, gymnosperms-angiosperms, monocotyledons-dicotyledons and whether mushrooms are plants or not and made incorrect explanations, made mostly correct scientific explanations and constructed systematic structures in which mislearnings decreased. In his study of conceptions of animal classification, Natadze (1963) once pointed out that when the visual images of an object were not consistent with the essential features of its concept, not even the older children could become familiar with the concept. Our study shows that the student's plant classification was based mainly on their visual experiences.

The study of Krall et al. (2009) revealed similarities between non-scientific conceptions of the teachers had, and non-scientific conceptions reported in the research literature on elementary and middle school students' understanding of the concepts. Unfortunately, if teachers retain the same misconceptions, then as classroom teachers they may reinforce the misconceptions currently held by the students or have their students accept different erroneous ideas for particular topics (Cokadar, 2012).

\section{Conclusions}

The first step of this study supports the results of previous studies on the subject. University students have alternative learnings about the plant kingdom and its classification. Students usually develop this kind of information in and out of school before they take 'General Biology' lesson about the subject in the undergraduate program. Students consider morphological elements and similarities, as in the form of Aristotle's classical classification, while classifying plants. As a result of this study, it was determined that Porphyrios tree activities are effective in removing pre-determined misconceptions. A fall was detected when the number of misconceptions that the students have before the application compared with the number of misconception after they were made to interact with Porphyrios tree.

Students' alternative conceptions arise out of an interconnected system of beliefs: about the nature of science, of learning, of the natural and social world. Cross-cultural perspectives on these world views are therefore essential. In order to remove mislearnings, which pose an important obstacle in the learning process, the following recommendations can be offered in the context of this study in which the Porphyrios tree instrument was used.

Techers should first remove misconceptions of students so that students can learn new concepts in a meaningful context. To do so, misconceptions should be detected in the first place. Teachers should be able to use different methods and materials for this aim. Therefore, teachers should be informed about concept teaching and misconceptions. Students' conceptual changes should be studied in different age groups from the start of primary education and causes of their learning difficulties and misconceptions should be identified. The effectiveness of visual instruments in this technique, such as Porphyrios tree, which are used to determine and remove mislearnings, can be found with research that will be conducted. Whether the Porphyrios tree is effective in other subjects and at different stages should be researched and ways of application specific to this instrument should be determined. 
In this study it is assumed that the Porphyrios tree is a useful instrument which can be used to attain the university sutdent's intuitive ideas about the classification of plants. However, there are limitations as to the validity of this instrument in determining the correct interpretation of the university student's mental structure. This study has a sample size of 54 individuals (eighteen students in three groups). Such a small number of subjects will certainly pose a restriction as to the generalizability of any findings. Consequently, one must assume that the systematic structures uncovered in this investigation are typical only to the subjects interviewed. This external validity can only be increased if similar research with larger, more representative groups of students is conducted in the future.

\section{References}

Adeniyi, E. O. (1985). Misconceptions of selected ecological concepts held by Nigerian students. Journal of Biological Education, 19 (4), 311-316.

Amir, R., \& Tamir, P. (1994). In-depth analysis of misconceptions as a basis for developing research-based remedial instruction: The case of photosynthesis. The American Biology Teacher, 56, 94- 100.

Bahar, M. (2003). Misconceptions in biology education and conceptual change strategies. Educational Sciences: Theory \& Practice (ESTP), 3 (1), 27-64.

Bell, B. F. (1981). When is an animal, not an animal? Journal of Biological Education, 15 (3), 213-218.

Bell, B. F., \& Barker, M. (1982). Towards a scientific concept of 'animal'. Journal of Biological Education, 16 (3), $197-$ 200.

Bilal, E., \& Erol, M. (2012). Effect of teaching via modeling on achievement and conceptual understanding concerning electricity. Journal of Baltic Science Education, 11 (3), 236-247.

Braund, M. (1991). Children's ideas in classifying animals. Journal of Biological Education, 25 (2), 103-110.

Braund, M. (1998). Trends in children's concepts of vertebrate and invertebrate. Journal of Biological Education, 32 (2), 112-118.

Brumby, M. (1979). Problems in learning the concept of natural selection. Journal of Biological Education, 2, 119122.

Brumby, M. (1984). Misconception about the concept of natural selection. Science Education, 68 (4), 493-503.

Cavallo, A. M. L., \& Schafer, L. E. (1994). Relationships between students' meaningful learning orientation and their understanding of genetics topics. Journal of Research in Science Teaching, 31, 393-418.

Chen, S. H., \& Ku, C. H. (1998). Aboriginal children's alternative conceptions of animals and animal classification. Proceedings of the National Science Council Part D, Mathematics, Science and Technology Education, 8 (2), 55-67.

Chunawala, S. et al. (1996). Diagnosing learning in primary science, Part l: Students' ideas relating to living and non-living. Mumbai (Bombay): Homi Bhabha Centre for Science Education.

Clough, E. E., \& Wood-Robinson, C. (1985). Children's understanding of inheritance. Journal of Biological Education, 19, 304-310.

Cohen, L., \& Manion, L. (1989). Research methods in education. 3rd edition, New York, Routledge.

Cokadar, H. (2012). Photosynthesis and respiration processes: Prospective teachers' conception levels. Education and Science, 37 (164), 81-93.

Dikmenli, M, Çardak, O., \& Türkmen, L. (2002). Elementary school students' alternative views about "animals kingdom and classification" concepts. V. National Science and Mathematics Education Congress, Proceedings, p. 69-73, METU Cultural and Convention Center, Ankara, Turkey.

Doğan, Ö. (1999). Max Weber: Science and sociology. I. section, Küyerel Publications, second edition, Turkey.

Doug, B. (2011). Misunderstanding the unambiguous: Student misconceptions in phylogenetic systematics. ProQuest Dissertations and Theses, Master of Science in Biological Science, California State University.

Driver, R. (1981). Pupils' alternative frameworks in science. European Journal of Science Education, 3, 93-101.

Fisher, K. M. (1985). A misconception in biology: Amino acids and translation. Journal of Research in Science Teaching, 22, 53-62.

Friedler, Y., Amir, R., \& Tamir, P. (1987). High school students' difficulties in understanding osmosis. International Journal of Science Education, 9, 541-551.

Gilbert, J. K., Osborne, R. J., \& Fensham, P. J. (1982). Children's science and its consequences for teaching. Science Education, 66, 623-633.

Goldin, G. (1998). Observing mathematical problem solving through task-based interviews. (Ed. A. R. Teppo). Qualitative Research Methods in Mathematics Education, (40-62) (Monograph No. 9, Journal for Research in Mathematics Education).

Griffiths, A. K., \& Grant, B. A. C. (1985). High school students' understanding of food webs: Identification of a learning hierarchy and related misconceptions. Journal of Research in Science Teaching, 22 (5), 421-436.

Kargbo, D., Hobbs, T., \& Erickson, G. L. (1980). Student beliefs about inherited characteristics. Journal of Biological Education, 14 (2), 137-146. 
Krall, R. M., Lott, K. H., \& Wymer, C. L. (2009). Inservice elementary and middle school teachers' conceptions of photosynthesis and respiration. Journal of Science Teacher Education, 20, 41-55.

Kubiatko, M., \& Prokop, P. (2007). Pupils' misconceptions about mammals. Journal of Baltic Science Education, 6 (1), 5-14.

Looft, W. R. (1974). Animistic thought in children: Understanding the "living" across its associated attributes. Journal of Genetic Psychology, 124, 235-240.

Marek, E. A. (1986). Understandings and misunderstandings of biological concepts. The American Biology Teacher, 48, 37-40.

Marek, E. A., Cowan, C. C., \& Cavallo, A. M. L. (1994). Students' misconceptions about diffusion: How can they be eliminated? The American Biology Teacher, 56, 74-77.

Meir, E., Perry, J., Herron, J. C., \& Kingsolver, J. (2007). College students' misconceptions about evolutionary trees. The American Biology Teacher, 69 (7), 71-76.

Natadze, R. G. (1963). The mastery of scientific concepts in school. In B. Simon \& J. Simon (Eds.), Educational Psychology in the USSR, London: Routledge \& Kagan Paul.

Natarajan, C. (1996). Students' ideas about plants - DLIPS, Part II. Mumbai (Bombay): Homi Bhabha Centre for Science Education.

Natarajan, C., Chunawala, S., Apte, S., \& Ramadas, J. (2002). Lessons for teaching botany: What middle school students know about plants. Homi Bhabha Centre For Science Education, TIFR, Mumbai, India.

Odom, A. L., \& Barrow, L. H. (1995). Development and application of a two-tier diagnostic test measuring college biology students' understanding of diffusion and osmosis after a course of instruction. Journal of Research in Science Teaching, 32, 45-61.

Ramadas, J. (1996). Diagnosing learning in primary science, Part III. Mumbai (Bombay): Homi Bhabha Centre for Science Education.

Sander, M. (1993). Erroneous ideas about respiration: The teacher factor. Journal of Research in Science Teaching, 30, 919-934.

Smith, E. L., \& Anderson, C. W. (1984). Plants as producers: A case study of elementary science teaching. Journal of Research in Science Teaching, 21 (7), 685-698.

Stewart J. H., \& Dale, M. (1989). High school students' understanding of chromosome/gene behaviour during meiosis. Science Education, 73, 501-521.

Stewart, J. H., Hafner, B., \& Dale, M. (1990). Students' alternate views of meiosis. The American Biology Teacher, 52, 228-232.

Storey, R. D. (1991). Textbook errors and misconceptions in Biology: Cell metabolism. The American Biology Teacher, 53, 339-343.

Tekkaya, C., Çapa, Y., \&Yılmaz, Ö. (2000). Misconceptions of biology teacher candidates about general biology issues. Hacettepe University Journal of Education, 18, 140-147.

Trowbridge, J. E., \& Mintzes, J. J. (1985). Students' alternative conceptions of animals and animal classification. School Science and Mathematics, 85 (4), 304-316.

Trowbridge, J. E., \& Mintzes, J. J. (1988). Alternative conceptions in animal classification: A cross-age study. Journal of Research in Science Teaching, 25 (7), 547-571.

Webb, P., \& Boltt, G. (1990). Food chain to food web: A natural progression? Journal of Biological Education, 24 (3), 187-190.

Westbrook, S. L., \& Marek, E. A. (1991). A cross-age study of student understanding of the concept of diffusion. Journal of Research in Science Teaching, 28, 649-660.

Westbrook, S. L., \& Marek, E. A. (1992). A cross-age study of student understanding of the concept of homeostasis. Journal of Research in Science Teaching, 29, 51-61.

White, R. T., \& Gunstone, R. (1992). Probing understanding. New York: Falmer Press.

Yin, R. K. (1994). Case study research: Design and methods. 2d Edition. Thousand Oaks, CA: Sage Publications.

Zukerman, J. T. (1994). Problem solvers' conceptions about osmosis. The American Biology Teacher, 6, 22-25.

Selami Yangin PhD., Assistant Professor, Department of Elementary Science Teaching, Recep Tayyip Erdogan University, Education Faculty, Cayeli - Rize, Turkey. E-mail: selami.yangin@erdogan.edu.tr

Tel.: +90 04645328454 / 2354.

Fax: +90 04645328612 .

Website: http://www.rize.edu.tr/akademisyen/akademisyen.asp?id=288 